\title{
Natręctwo niepamięci naszej o Zagładzie
}

Marek Zaleski

TEKSTY DRUGIE 2016, NR 6, S. 90-105

DOI: $10.18318 /$ td.2016.6.7

1.

Od razu wytłumaczę się ze sformułowania w tytule mojego tekstu. Natręctwo niepamięci rozumiem jako przymus konstruowania zapomnienia. Owo zapomnienie jest formą niepamięci kontrolowanej - niepamięci, która pojawia się jako reakcja obronna. Nie jest więc zwykłym zapominaniem, ale spychaniem w milczenie, często „wspomnieniem przesłonowym”, które służy zbiorowej pamięci o przeszłości. Wszelako służy w sposób szczególny: w takim jej wymiarze, w jakim pamięć jest znakiem tożsamości etnicznej, rzekomo zagrożonej. Dopowiem też bez zwłoki: zastrzeżenie, że można mieć wątpliwości, czy służy jej dobrze, uznaję w tym wypadku za eufemizm. Jest katastrofą tejże pamięci i jej mechanizmem patogennym. Z kolei czynny tutaj przymus (resp. kompulsja) jest reakcją afektywnie wymuszoną, ale zarazem dopełnioną całą gamą zabiegów reżyserowanych, przedsięwziętych $\mathrm{w}$ imię manipulacji pamięcią. Zresztą w procesie pamiętania dokonują się nieustanne transfery między nieświadomością i świadomością i redystrybucja znaczeń powstających w obu tych porządkach. Owo natręctwo

\footnotetext{
Marek Zaleski (1952)

- profesor zwyczajny, kierownik Zespołu do Badań nad Literaturą i Kulturą Późnej Nowoczesności w Instytucie Badań Literackich PAN. Ostatnio opublikował zredagowaną wraz z Adamem Lipszycem książkę zbiorową Ciała zdruzgotane, ciała oporne. Lektury afektywne XX wieku (2015). Kontakt: marek.marzales@ gmail.com
} 
kompulsywnej, ale i świadomie fabrykowanej niepamięci interesuje mnie tutaj jako mechanizm czynny w konstruowaniu pamięci polskiej o Zagładzie, a więc o zagładzie współobywateli, polskich Żydów, która dokonała się w latach ostatniej wojny.

Rozbrajając ów mechanizm, warto mieć na uwadze słowa Freuda o celu postępowania terapeutycznego. Freud był pesymistą i w postępowaniu ze swoimi pacjentami upatrywał nadziei na zastąpienie nerwicy „zwyczajnym poczuciem nieszczęścia"1. Dlaczego warto mieć na względzie ową powściągliwość Freuda jako terapeuty? Analiza przynosi samopoznanie, które bywa gorzką wiedzą, podobnie jak badanie historycznej przeszłości. Od szukania powodu do dumy ważniejsze jest takie potraktowanie klęsk, które spowoduje, by związane z nimi urazy nie powracały. Lepiej istnieć we współczesnym świecie na prawach suwerennego, choć nieszczęśliwego podmiotu, niż kompensować sobie nieszczęścia za cenę życia w fałszywym imaginarium.

Aleksander Herz w swoim studium Żydzi w kulturze polskiej (1961) analizował „kwestię żydowską” jako „kwestię polską”, czyli jako problem, który polska społeczność miała i ma, jego zdaniem, ze sobą. Ten sposób podejścia wydaje się nadal właściwy.

Jeżeli o ofierze jakiejś społeczności można powiedzieć, że jest jej symptomem (jak jest nim „Żyd” dla Polaków), staje się wówczas oczywiste, że społeczność ta trzyma się razem poprzez silne przywiązanie do intensywnej negatywnej rozkoszy - do jouissance

- zauważa Renata Salecl². Tymczasem „psychoanaliza zawsze traktowała podmiot jako odpowiedzialny za własną jouissance. Już Freud pisał przecież

1 Rozprawę Psychoterapia histerii (1895) kończy Freud wyimaginowanym dialogiem z pacjentem, w którym pada zdanie: „Niewątpliwie zmiana twojego losu [chodzi tu o okoliczności i warunki życia pacjenta - M.Z.] przyczyniłaby się do uzdrowienia cię z twojej choroby bardziej niż moje staranie. Ale wiele zdołamy osiągnąć, jeśli uda nam się przekształcić twoje histeryczne schorzenie w zwyczajne nieszczęście". Cyt. za: S. Freud The Complete works, ed. I. Smith, HolyBooks. com, 2000, 2007, 2010, s. 269 (pdf-ebook), cyt. za: https://www.valas.fr/IMG/pdf/Freud_Complete_Works.pdf, s. 269 (10.07.2016). Jay M. Winter tę uwagę Freuda wykorzystuje do polemiki z koncepcją "pamięci fortunnej” Paula Ricoeura jako pamięci wolnej od urazu wrogości wobec dawnego oprawcy. Por. J.M. Winter O milczeniu, w: (Kon)teksty pamięci. Antologia, red. K. Kończal, przeł. E. Bagłajewska-Miglus i in., Narodowe Centrum Kultury, Warszawa 2014, s. 394.

2 R. Salecl (Per)wersje miłości i nienawiści, przeł. Ł. Mokrosiński, Wydawnictwo Subversion, Warszawa 2009, s. 192. 
o wyborze nerwicy"3. Polską rozkoszą jest obsadzanie się w roli ofiary. Nie tylko ofiary obcej przemocy, ale także ofiary spisku. I dziś także Polacy są ciągle zakładnikami swojej fantazmatycznej kondycji bardziej niż powinni, bo ciągle są na uwięzi swojej ciemnej jouissance. Aby się od niej uwolnić, muszą nie tylko rozpoznać swój symptom (który szyfruje ich jouissance), ale i wziąć zań odpowiedzialność. Uświadomić sobie zatem, z jakiego powodu wybierają "Żydów” jako swój symptom, dlaczego pozostają we władzy takich, a nie innych reakcji i zachowań, mówią o tym w sposób, w jaki mówią ${ }^{4}$.

A owe reakcje w stosunku do żydowskich współobywateli wydają się niezmienne od końca wojny. Składają się na nie wypierana i zacierana od samego początku pamięć o Zagładzie ${ }^{5}$, mająca swój symboliczny epilog w postaci rozprawy z autorami hasła w encyklopedii PWN, łatwość, z jaką społeczeństwo polskie uległo propagandzie w marcu'68, oburzenie, z jakim spotykały się kolejne książki Jana Tomasza Grossa, i skandalizowanie jego wystąpień' ${ }^{6}$ oraz cała

3 Tamże, s. 193.

4 Socjologowie wskazują tu na rywalizację Polaków w wyścigu ofiar. Antoni Sułek zauważa, że „niedocenianie martyrologii Żydów nie jest sprawą ignorancji, bo Polacy dobrze wiedzą, że prawie wszyscy Żydzi zostali zamordowani. Polacy - jest to znana już teza Ireneusza Krzemińskiego - mają rywalizować z Żydami o pierwszeństwo w cierpieniu, ma im ono dawać poczucie moralnej wyższości. Być może Polacy nie tyle chcą być pierwszymi, ile nie chcą być drugimi, ale w każdym razie własne męczeństwo czasu wojny należy do ich tożsamości społecznej. «Europa powinna uznać nasze prawo do tej osobnej ofiary, bez mówienia o niej w języku konkurencji» - napisał niedawno Paweł Śpiewak po przeczytaniu Powojnia, tworzącej opinię świata książce Tony Judta; z jej epilogu wynika, że "«Żydzi byli głównymi i niemal jedynymi ofiarami wojny w Europie»”. A. Sułek Zwykli Polacy patrz̨ na Żydów, „Nauka Polska” 2010 nr 1, s. 20-21.

5 Por. książkę laureatki Nagrody Historycznej „Polityki” Zofii Wójcickiej Przerwana żałoba: Polskie spory wokół pamięci nazistowskich obozów koncentracyjnych i zagłady 1944-1950, wydaną w roku 2009 przez warszawskie wydawnictwo Trio (ang. wydanie: Arrested mourning: memory of the nazi camps in Poland, 1944-1950, Peter Lang Publishing House, Frankfurt am Main 2013), książkę Grzegorza Niziołka Polski Teatr Zagłady, Instytut Teatralny im. Zbigniewa Raszewskiego, Wydawnictwo „Krytyki Politycznej”, Warszawa 2013, artykuł Barbary Törnquist-Plewa The use and non-use of the holocaust memory in Poland, w: Painful pasts and useful memories remembering and forgetting in Europe, ed. B. Törnquist-Plewa, N. Bernsand, The Centre for European Studies (CFE) at Lund University, Lund 2012 czy zupełnie ostatnio tekst Henryka Grynberga Przewodnik po kłamstwie, dwutygodnik.com 2016 nr 195, http://www.dwutygodnik.com/artykul/6769-przewodnik-po-klamstwie.html (20.10.2016).

6 Szczególnie znamienna jest polska recepcja felietonu Grossa (zamieszczonego na stronie ProjectSyndicate i przedrukowanego m.in. przez „Die Welt"), w którym pojawiło się przypuszczenie, że Polacy w czasie wojny zabili więcej Żydów niż Niemców. Por. http://www.newsweek.pl/polska/jan-tomasz-gross-o-tym-dlaczego-polacy-nie-chca-uchodzcow-debata-wkp,artykuly,370968,1.html (19.07.2016). 
historia reakcji na zbrodnię w Jedwabnem, zakończona epilogiem, jakim były niedawne wystąpienia nowego dyrektora Instytutu Pamięci Narodowej i Minister Edukacji Narodowej, kwestionujące ustalenia historyków7. Nie wspominam już o mowie nienawiści zalewającej fora internetowe jako rządzące się, według niektórych, szczególną pragmatyką, ale warto wspomnieć, że i w epoce przedinternetowej sytuacja nie wyglądała inaczej: po publikacji eseju Błońskiego Biedny chrześcijanin patrzy na getto redakcję „Tygodnika Powszechnego” zalała fala nienadających się do druku listów od oburzonych czytelników. Jeśli wierzyć sondażom, w społeczeństwie polskim antysemici stanowią mniejszośśc ${ }^{8}$, zarazem respondenci deklarują, że Żydzi nie ucierpieli w czasie wojny bardziej aniżeli Polacy ${ }^{9}$ Żeby wyznawać taki pogląd nie trzeba być antysemitą,

7 Por. Kandydat na szefa IPN o Jedwabnem: Wykonawcami tej zbrodni byli Niemcy, którzy wykorzystali - pod przymusem grupkę Polaków, http://wyborcza.pl/1,75398,20424470,kandydat-na-szefa-ipn-o-jedwabnem-wykonawcami-tej-zbrodni-byli.html (19.07.2016);

Anna Zalewska w Kropce nad i (emisja 13.07.2016), http://www.tvn24.pl/wiadomosci-z-kraju,3/anna-zalewska-w-kropce-nad-i-o-jedwabnem-i-pogromie-kieleckim,660799.html (19.07.2016). Owe wystąpienia odnowiły debatę polityczną w mediach na temat pogromów w Jedwabnem i w Kielcach i ich upamiętnianiu, a wystapienie Minister Zalewskiej spowodowało także protest grupy historyków i nauczycieli (por. http://wyborcza.pl/7,75398,20437437,wybitni-historycy-zajmujacy-sie-zaglada-protestuja-szokujace.html (19.07.2016) oraz http:// wyborcza.pl/1,75398,20483524,nauczyciele-przeciw-manipulowaniu-historia-ostry-list-po-slowach.html (19.07.2016).

8 Zarazem jednak z raportu z badań przeprowadzonych przez CBOS w roku 2015 wynika, że w ostatnich 20 latach stosunek Polaków do Żydów poprawił się. O ile w pierwszej połowie lat 90. ponad trzykrotnie więcej osób deklarowało niechęć do nich niż sympatię, o tyle od kilku lat odsetki te są zbliżone. "Mimo poprawy stosunku do Żydów, nadal nie należą oni do grona najbardziej lubianych przez Polaków narodów" - dodano. Dziś 32 proc. respondentów odnosi się do Żydów niechętnie, a 28 proc. - z sympatią. Cyt. za: J. Guzik CBOS: Żydzi w czasie II wojny światowej doznali od Polaków więcej dobrego niż złego, "Rzeczpospolita” 14 sierpnia 2015, http://www.rp.pl/Historia/308149916-CBOS-Zydzi-w-czasie-II-wojny-swiatowej-doznali-odPolakow-wiecej-dobrego-niz-zlego.html\#ap-1 (13.07.2016).

9 Jak czytamy w styczniowym numerze tygodnika „Wprost" z roku 2008, "dyskusja wokół kontrowersyjnych książek prof. Jana T. Grossa pomaga w zrozumieniu historii trudnych relacji polsko-żydowskich - wynika z badań opinii publicznej. Pentor na zlecenie «Wprost» zapytał Polaków o wojenne doświadczenie obu narodów. Wyniki porównaliśmy z podobnym sondażem, który w 1995 r. przeprowadził Demoskop. Trzynaście lat temu aż niemal połowa badanych (49 proc.) była zdania, że Polacy zrobili wystarczająco dużo, by pomóc Żydom w czasie II wojny światowej, 26 proc. twierdziło, że zrobili tyle, ile mogli w tamtych warunkach. Obecnie proporcje się odwróciły. Jednoznacznie pozytywnie skalę pomocy Polaków dla Żydów ocenia tylko 24 proc. ankietowanych przez Pentor. [...] Przez 13 lat niewiele zmieniła się odpowiedź Polaków na pytanie, kto bardziej ucierpiał w czasie wojny: Polacy czy Żydzi. Podobnie jak w 1995 r. najwięcej z nas uważa, że oba narody ucierpiały po równo (w 1985 r. - 40 proc., w 2008 r. -52 proc.)", cyt. 
ale obserwatora dyskursu publicznego w Polsce zastanawia jednak, dlaczego agresywna "neurotyczna mniejszość" nie spotyka się z bardziej zdecydowaną dezaprobatą.

\section{2.}

Powtarzalność reakcji każe myśleć o ich kompulsywnym charakterze, właściwym nerwicy natręctw: w tym wypadku odruch oburzenia zdaje się wynikiem wewnętrznego przymusu. Podmiot czuje się przymuszony do takiego właśnie działania lub do myślenia i nawet jeśli walczy z tą siłą, „karze się za swój brak oburzenia”, odczuwany jako „wywołujący w nieunikniony sposób lęk"10. To nerwica ofiary żyjącej w lęku przed oskarżeniem o bycie oprawcą, wstyd zamieniony w agresję. Afektywność reakcji stymuluje upajanie się fatalizmem polskiego losu (losu ofiary, zmowy obcych), wzmacniając strukturę obsesyjną i pracując na rzecz autowiktymizacji. Wszelako wikty-

za: https://www.wprost.pl/forum/121842/16642/Pan-Gro-nomen-omen.html (13.07.2016). Jak wynika z przeprowadzonych w 2015 roku badań CBOS, „obecnie 26 proc. uważa, że Żydzi doznali od Polaków więcej dobrego niż złego. 44 proc. jest zdania, że Żydzi doświadczyli równie dużo dobrego co złego, a 11 proc - że więcej złego niż dobrego. 19 proc. nie ma opinii. [...] Dominowało i nadal dominuje przekonanie, że Polacy doświadczyli od Żydów tyle samo dobrego co złego - uważa tak dziś 49 proc."; CBOS pytał też o reakcje na "doniesienia o zbrodniach popełnionych przez Polaków na Żydach". Były to: współczucie dla ofiar (36 proc. wskazań); potępienie sprawców (34 proc.); poruszenie, że "ludzie ludziom zgotowali taki los" (29 proc.); „wstyd, że doszło do takich zbrodni” (26 proc.); oburzenie, że „tyle mówi się o zbrodniach Polaków na Żydach, a za mało o Polakach, którzy ratowali Żydów" (25 proc.); oburzenie na "tych, którzy szkalują dobre imię Polski i Polaków" (13 proc.); oburzenie, że „tyle mówi się o zbrodniach Polaków na Żydach, a nic się nie mówi o zbrodniach Żydów na Polakach" (13 proc.); wątpliwość, "czy rzeczywiście Polacy byli sprawcami takich zbrodni” (11 proc.) oraz niewiedza, "że w czasie okupacji Polacy mordowali Żydów" (9 proc.). 5 proc. wyraziło opinię: „nie obchodzi mnie to”. Większość badanych - 55 proc. - jest przekonana, że w czasie wojny więcej było "przypadków ukrywania Żydów przez Polaków i pomagania im, niż donoszenia na nich i mordowania". 22 proc. uważa, że obie postawy były tak samo częste. O tym, że więcej było "donoszenia i mordowania", przekonanych jest 7 proc. 15 proc. nie ma zdania. Jak podaje CBOS, w ocenie 71 proc. ankietowanych nie można zapominać o "mordach i pogromach dokonywanych przez Polaków na Żydach w czasie wojny i tuż po niej". Zarazem przeważa jednak pogląd (48 proc.), że były to incydenty, których „nie należy uogólniać”. 23 proc. uważa, że takie przypadki trzeba ujawniać i nagłaśniać - „tak byśmy znali całą prawdę o sobie”. 22 proc. uważa, że to „zamierzchła historia” i „nie ma co rozgrzebywać starych ran". 7 proc. "nie ma opinii". Przytaczam za: J. Guzik CBOS: Żydzi w czasie Il wojny...

10 J. Laplanche, J.-B. Pontialis Natręctwo, w: Słownik psychoanalizy, przeł. E. Modzelewska, E. Wojciechowska, Wydawnictwa Szkolne i Pedagogiczne, Warszawa 1996, s. 149. 
mizacji perwersyjnej, bo patos zapewnia gratyfikację. Rola ofiary i poczucie krzywdy uwzniośla. Czynne tu racjonalizacje i zachowania obronne ulegają rytualizacji zwłaszcza w chwilach domniemanego zagrożenia. Właśnie czynna tu kompulsywność wymusza nieprzyjmowanie do wiadomości ustaleń historyków i spełnia się w repetycji sprzeciwu wobec nich jako nieprawdziwych i oszczerczych.

Freud w rozprawie Przypominanie, powtarzanie, przepracowanie (1914) za główny powód trudności w przywoływaniu traumatycznych doświadczeń uznaje blokowanie wspomnień: wyparcie, które realizuje się przez przymus powtarzania, czyli pochodzący z nieświadomości proces, w wyniku którego

podmiot naraża się na przykre sytuacje, powtarzając w ten sposób dawne doświadczenia, lecz nie przypominając sobie pierwowzoru, przeciwnie: ma on nieodparte wrażenie, że jego sytuacja jest całkowicie uwarunkowana aktualnymi okolicznościami. ${ }^{11}$

Freud powiada, że pacjent zamiast pamiętać i przepracowywać tym samym treści doświadczenia urazowego, powtarza je tylko, fiksując się na pozycji patologicznej. W przypadku oburzonej neurotycznej mniejszości wyparte „próbuje powrócić w teraźniejszości” w klasycznej, podręcznikowej formie: nie tylko w formie udręczających myśli i obrazów, ale i w formie acting-outów, działań - na przykład w formie dyskursywnego zaangażowania w traumatyzujące treści, w mowie nienawiści, w wystąpieniach w obronie rzekomo znieważanego dobrego imienia Polski etc. Te zachowania mają typowy charakter powtarzania urazu w „przeniesieniu” (rolę analityka pełni tu Inny, wszelako selektywnie utożsamiany z afirmowaną przez siebie wspólnotą, albo z - tyleż demagogicznie, co z prostodusznie rozumianym - wysokim trybunałem opinii publicznej, który nie pozostanie głuchy na krzywdę niesprawiedliwie oskarżanych). Są więc bardziej symptomem trwania w chorobie, aniżeli przynależą do procesu terapeutycznego, czyli prawdziwego przeniesienia, utożsamianego z przepracowaniem urazu. Tym bardziej że czynna jest tu ciągle ekonomia afektywna, w myśl której - jak o tym Freud pisał także w późniejszych pracach - pod manifestującym się publicznie cierpieniem „niesłusznie” oskarżanych kryje się spełnienie pragnienia (tu: ciemna rozkosz bycia ofiarą).

Obsesyjnie ponawiany rytuał dawania odporu zmienia się w patologiczny mechanizm, który paraliżuje komunikację, utrwala syndrom ofiary. $\mathrm{Na}$

11 Przymus powtarzania, w: Słownik psychoanalizy, s. 266-267. 
rzecz tej niemożności pracuje dodatkowo polityka pamięci,jaką defensywnie wybiera zbiorowość za sprawą agresywnej neurotycznej mniejszości. Oficjalna wersja pamięci zbiorowej promuje partykularne wykładnie przeszłości i zaciera prawdę historycznego doświadczenia. W tym względzie zwłaszcza ostatnio w Polsce inscenizowana i forsowana jest służąca narodowym interesom etniczna interpretacja pamięci Zagłady. To, z czym mamy do czynienia, to polonizacja pamięci Zagłady, wpisująca się w „szaleństwo upamiętniania”, prowadzące do „konfiskaty pamięci” i nadużyć sprzyjających „dążeniu do utwierdzania się w pozie ofiary" - by sięgnąć po sformułowania Paula Ricoeura, które dla nas nabierają znajomej treści ${ }^{\mathbf{1 2}}$. Tymczasem w Europie i na świecie, akurat gdy chodzi o pamięć Zagłady, obserwujemy - zdaniem badaczy - tendencje odwrotne: partykularne polityki historyczne słabną, a „nowa przestrzeń pamięci Zagłady staje się powoli przestrzenią kosmopolityczną" i uniwersalną ${ }^{13}$.W przypadku Polski teza ta może wydawać się wątpliwa: jak czytamy w książce Michaela Rothberga, historie wiktymizacji rozmaitych grup etnicznych, w których dochodzą do głosu rywalizujące ze sobą pamięci zbiorowe, często, zwłaszcza tam, gdzie mamy do czynienia z zależnościami postkolonialnymi (a z taką sytuacją mieliśmy do czynienia w PRL, państwem pod obcą dominacją), „przyjmują formę walki o prymat”14.

Wielokierunkowa pamięć, o którą zabiega Rothberg, polega na tym, że reprezentacje Zagłady przekraczają czas i przestrzeń tego, co reprezentują, zaczynają żyć własnym życiem, stają się podstawą zdominowanego przez post-pamięć zbiorowego pamiętania, są pluralistyczne i konstytuują wielogłos wspólnot interpretacyjnych, gdy tymczasem w Polsce, nie licząc akademickich ośrodków takich jak Centrum Badań nad Zagładą Żydów IFIS PAN, Żydowski Instytut Historyczny, Muzeum Żydów Polskich czy do niedawna Instytut Pamięci Narodowej, w dyskursie publicznym przeważają repetycje rywalizujących narracji. Po okresie spluralizowania dyskursu o Zagładzie znajdującym kulminację w roku 2002, kiedy to z udziałem ówczesnego prezydenta Polski upamiętniono oficjalnie ofiary mordu jebwabieńskiego, zaczyna się więc niepokojąco odtwarzać nie tylko zapoczątkowany już zaraz po wojnie mechanizm wytwarzania „oddzielnych” i „nacjonalizowanych porządków pamiętania” (żałoba „polska” i „żydowska”), o którym pisała Wójcicka, ale

\footnotetext{
P. Ricoeur Pamięć, historia, zapomnienie, przeł. J. Margański, Universitas, Kraków 2006, s. 114.

Por. D. Levy, N. Szneider Holocaust jako polityka historyczna, w: (Kon)teksty pamięci..., s. 171.

M. Rothberg Pamięć wielokierunkowa. Pamiętanie Zagłady w epoce dekolonizacji, przeł. K. Bojarska, Wydawnictwo IBL PAN, Warszawa 2015, s. 15.
} 
i zaczyna odtwarzać się międzypokoleniowa luka pamięciowa, meblowana przez wysłużone fantazmaty.

Pamięć zbiorowa zamieszkuje krajobraz kontrolowanego zapomnienia. Ale nie znaczy to, że stanowi przestrzeń poddaną kontroli całkowitej. Nakaz niepamięci nie usuwa traumatyzujących zdarzeń z nieświadomości, w której, według Freuda, przebywa pamięć. Zapomnienie więc nie usuwa tego, co oburza tych, którzy pamięć dziedziczą, nabywają w procesie identyfikacji z narodową przeszłością. Co najważniejsze, nie jest wcale istotne, czy są to doświadczenia przeżyte osobiście, czy tylko treści przyswojone wtórnie, w procesie uczestnictwa w życiu wspólnoty. Jak bowiem dobrze wiadomo, reprezentacje pamięci traumatycznej nie wiążą się jedynie z minionymi zdarzeniami bądź przedmiotami pamięci, ale z jej teraźniejszym doświadczeniem. Uczestnicy dyskursu na temat budzącej emocje przeszłości są w sytuacji uczestników spektaklu, który, jak powiada Jill Bennett, „odgrywają wobec siebie swoje uczucia"15. Właśnie z uwagi na to pamięć tych z drugiego i trzeciego pokolenia jest równie afektywna jak pamięć pokolenia uczestników i świadków. Dlatego i oni również poddani są przymusowi kompulsywnych repetycji ${ }^{16}$.

\section{3.}

„Regułą w historii wydaje się to, że po klęskach chroni się własną dumę", zauważa Christian Meier"17. Dlaczego jednak wiedza o niechwalebnej i budzącej uczucie wstydu przeszłości jest tak trudna do przyjęcia? Pamięci indywidualnej nikt z nas sobie nie wybiera, do pamięci zbiorowej dokonujemy akcesu.

Pamięć zbiorowa - podkreśla Wulf Kansteiner - zdaje się zamieszkiwać nie w postrzegającej świadomości, ale w tym, co materialne, w praktykach i instytucjach życia społecznego i psychicznego, które w nas funkcjonują,

15 J. Bennet Wnętrza, zewnętrza:trauma, afekt i sztuka, w: Pamieć i afekty, przeł. A. Kowalcze-Pawlik, T. Bilczewski, Wydawnictwo IBL PAN, Warszawa 2014, S. 149.

16 „Tak zwana pamięć traumatyczna przenosi ze sobą do teraźniejszości i przyszłości doświadczenie, w ramach którego wydarzenia są ponownie kompulsywnie oświadczane tak, jakby między przeszłością a teraźniejszością nie istniała żadna odległość ani różnica", D. LaCapra Historia w okresie przejściowym. Doświadczenie, tożsamość, teoria krytyczna, przeł. K. Bojarska, Universitas, Kraków 2009, s. 76. 
ale, co dziwne, nie wydają się potrzebować ani naszego uczestnictwa, ani naszej lojalności. ${ }^{\mathbf{1 8}}$

Można by rzec, że owe praktyki i instytucje wyposażające pamięć zbiorową ucieleśniają Innego. Do pamięci zbiorowej dokonujemy akcesu właśnie w taki sposób, że nasze zaangażowanie jest odpowiedzią na interpretację Innego, jest próbą udzielenia odpowiedzi na pytanie o to, kim jestem. Atak na treści sankcjonowane przez pamięć zbiorową budzi lęk i zgrozę, bo jest poniekąd atakiem na Innego. Jeśli zostajemy oskarżeni i zawstydzeni, to tym samym Inny w nas zostaje oskarżony, to Inny w nas się wstydzi. Wstyd, jak zauważa Renata Salecl, jest nie tylko oznaką niepewności i zmieszania samego podmiotu, ale i skutkiem podważenia czy krachu autorytetów, widmem mankamentów Innego.

Kiedy się wstydzę, nie tylko staram się uniknąć pełnego dezaprobaty spojrzenia Innego, przed którym stoję upokorzony. Odwracając wzrok, próbuję również nie dostrzegać i tego, że sam Inny jest pełen mankamentów albo, dopowiadając do końca, próbuję ukryć przed sobą to, że Inny nie istnieje. ${ }^{19}$

Nic więc dziwnego, że bronimy się przed oskarżeniami i staramy się nie dopuścić do siebie uczucia wstydu. Wraz ze wstydem pojawia się lęk, który jak podkreśla Salecl - dotyczy spraw dla nas najbardziej istotnych: podmiot przestaje doświadczać siebie jako spełnienia pragnienia Innego, staje się więc bezradny i opuszczony: to, co meblowało jego świat, wali się w gruzy. Pociąga to za sobą istotne konsekwencje. Jakkolwiek odpowiedzialność rozpatrywana na gruncie pamięci zbiorowej dotyczy indywidualnej sprawczości, dla wspólnoty pamięć własnych zbrodni staje się dotkliwa w sposób skrajny, dotyka bowiem tożsamości narodowej. Oskarżony o zbrodnie uczestnik wspólnoty, daleki potomek winnych tamtej zbrodni, odtąd depozytariusz winy zbiorowej, zostaje postawiony w sytuacji, która zmusza do zakwestionowania własnej tożsamości, w interesującym nas tutaj wypadku tożsamości wspólnoty niewinnych ofiar historii. Konfrontacja z oskarżeniem zmusza do „rozbicia

18 W. Kansteiner Szukanie znaczeń w pamięci: metodologiczna krytyka pamięcioznawstwa, w: (Kon) teksty pamięci..., s. 236.

19 R. Salecl Nobody home, "Cabinet” 2008 Issues 31, http://cabinetmagazine.org/issues/31/salecl. php (20.07.2016). 
fantazmatycznego scenariusza podtrzymującego tożsamość"20 osoby oskarżanej. Obiektem zagrożonym jest „niemożliwe do usymbolizowania jądro w Innym: obiekt a" (tu: wiecznie zagrożona przez historię polskość jako fundament jej tożsamości). „To wokół niego podmiot kształtuje swój fantazmat, swój scenariusz tymczasowej całościowości" - powiada Salecl. Jego jądrem pozostaje więc to, co trudne do usymbolizowania i do artykulacji, odsyła do niekończącego się szeregu swoich substytucji, będących kolejną osnową argumentowania, raz mniej lub zgoła wcale (w obiegu prasowym), raz bardziej (w akademickim) subtelnego. Rozmowa jest tak trudna właśnie dlatego, że

tożsamość każdej osoby zakorzeniona jest w obiekcie a, więc oskarżana osoba nie może się bronić poprzez odwołanie się do „prawdy" lub poprzez krytykę ideologii stanowiącej fundament w jej mniemaniu oszczerczego, oskarżycielskiego ataku,

bo to dwa różne porządlki: afektywny i racjonalny. Obiekt a wytwarza pole afektywne, argumenty w istocie przestają się liczyć, a dyskusja jest utrudniona. Salecl podkreśla, że mowa oskarżycielska godząca w obiekt a jako fundament tożsamości dlatego jest tak krzywdząca i w przekonaniu oskarżonego tak podstępna, bo wykorzystuje jego strukturalną niejako bezbronność: czuje się ugodzony w tym, co dla niego najdroższe i trudne do wysłowienia. Wydaje się, że tak są przyjmowane argumenty tych, którzy dokonują opisu sytuacji nie po myśli rzeczników wspólnoty - vide reakcja na książki i artykuły Jana Tomasza Grossa, którego tezy znajdują przecież poparcie części historyków²1.

R. Salecl (Per)wersje miłości..., s. 188 i n.

Marcin Zaremba, autor Wielkiej trwogi, pisał: „Autorzy szacują, że po 1942 r. kilkadziesiąt tysięcy Żydów zostało zamordowanych przez Polaków. Wiemy na pewno i jest to udokumentowane, że zabili oni co najmniej tysiąc Żydów, kilka tysięcy wydali Niemcom. Środowisko polskich historyków Holocaustu podziela przekonanie, że te liczby to jedynie wierzchołek góry lodowej. Badania trwają. Wiemy, że około 200-250 tysiącom Żydów udało się zbiec z gett i wagonów jadących do obozów zagłady. Przeżyło około 40-60 tysięcy. Co zatem stało się z resztą? Czy wszyscy zginęli z rąk Polaków? [...] Jakiś procent trzeba złożyć na karb naturalnej przyczyny zgonów. [...] Nawet gdyby aż połowa (co jest nieprawdopodobne) ukrywających się Żydów zmarła na skutek wycieńczenia, chorób, braku leków, nie zmieni to wymowy zbrodni. [...] Przyjmijmy jednak, że Grossowie mają rację i rzeczywiście kilkadziesiąt tysięcy Żydów Polacy uśmiercili widłami, siekierami bądź wydali Niemcom. Liczba ta przewyższa niemieckie straty osobowe w kampanii wrześniowej (17 tys. zabitych) i znacznie liczbę poległych żołnierzy Wehrmachtu w Powstaniu Warszawskim (ponad 2 tys.). Nie znam szacunków mówiących o stratach poniesionych przez Niemców na terenie okupowanej Polski od października 1939 r. do lata 
Ale właśnie: części. Znaleźli się natychmiast inni historycy (o publicystach nie wspominając), którzy potraktowali jego książki jako tendencyjne, naukowo bezwartościowe i pisane z obcej inspiracji, co polskiej minister pozwala powiedzieć, że udział Polaków w zbrodni w Jedwabnem to tylko „liberalna interpretacja”. Równie istotna jest reakcja na książki tych, którzy dokonując opisu, starają się dostarczyć narzędzi pomocnych do rozbrojenia urazu i zarazem fantazmatu. Mam na myśli Andrzeja Ledera, który w swojej książce Prześniona rewolucja, a i w udzielanych wywiadach podkreślał, że z przyczyn historycznych w społeczeństwie polskim poczucie krzywdy, zarówno to mające swoje źródło w niepodległościowej kulturze postszlacheckiej, jak i to wywodzące się z kultury popańszczyźnianej, jest czynnikiem budującym tożsamość i stanowi główną emocję polityczną, a „dwa wydarzenia, z których na dodatek duża część społeczeństwa profitowała”, to znaczy „nieprzepracowana pozycja świadka zagłady Żydów” (które to doświadczenie „było o wiele powszechniejsze niż na przykład udział w ruchu oporu"), podobnie jak doświadczenie „bycia świadkiem tego, co stało się po 1945 roku, czyli rozbicia dawnej struktury społecznej przez komunistów i Rosjan, wojny domowej, unicestwienia ziemiaństwa, terroru”, ,pozostawiły osad poczucia winy, paradoksalnie napędzający poczucie krzywdy"22. Mechanizm tych traumatyzujących zdarzeń przesłonięty snem o sprawiedliwości dziejowej, tłumaczy dlaczego zapomniane akty fizycznej i symbolicznej przemocy zbierają po dziś dzień swoje żniwo w postaci uporczywego trwania prześladowczego antysemickiego fantazmatu. U jego podstaw - zdaniem Ledera - znajdujemy odesłaną w niepamięć przeszłość dużej części dzisiejszej polskiej klasy średniej: wyparcie udziału w procesie Zagłady, przeżywanie go jako transpasywnego i stąd odrealnionego (doświadczanie własnego działania jako dokonującego się za pośrednictwem kogoś innego, działania przedsięwziętego nie w swoim

1944 r., czyli do rozpoczęcia akcji «Burza». Niemożliwe jednak, by przekroczyły one 3 tys. Jakie są zatem implikacje liczb przytoczonych przez Grossów? Ni mniej, ni więcej takie, że byliśmy, a przynajmniej chłopska część naszego społeczeństwa, nie po tej stronie, po której nam się wydawało, że byliśmy, skoro zabiliśmy więcej Żydów niż Niemców [...]. Grossowie zmuszają nas tym razem do przyznania, że Polacy mieli w czasie wojny krew na rękach. I to w imię czego? Złotych zębów. Dyskredytuje naszą heroiczną opowieść o ofierze". Biedni Polacy na żniwach, "Gazeta Wyborcza" 17 stycznia 2011, http://wyborcza.pl/1,76842,8951226,Biedni_Polacy_na_ zniwach___Recenzja__Zlotych_Zniw_.html (20.07.2016). dziernika 2016, http://www.polityka.pl/tygodnikpolityka/kraj/1635741,1,prof-andrzej-leder-opolskiej-duszy-i-poczuciu-skrzywdzenia.read (10.08.2016). 
imieniu) ${ }^{23}$.Zatem znowu inni szatani byli tam czynni: odpowiedzialność za aktywne uczestnictwo w mordowaniu, zakazana przyjemność i zarazem zgroza (jouissance) były cedowane na Niemców, co łagodziło poczucie winy. Charakter tego udziału określiło doświadczenie przeżywania swego pragnienia przez rodzimych sprawców przemocy jako pragnienia delegowanego na Niemców, prawdziwych sprawców i beneficjentów Zagłady, a zarazem na Innego będącego instrumentem sprawiedliwości dziejowej, bo przeżywana pasywnie prawdziwa pozycja mimowolnych współsprawców i świadków pozostawała funkcją afektów zdeponowanych w fetyszu Żyda - figurze złowrogiej inności). Z obcego nadania weszliśmy w posiadanie tego, co nam się niejako należało, a z czego zostaliśmy podstępnie wyzuci. Najpełniej tę postawę wyrażał locus communus po wojnie przytaczany przez wielu: „Cośmy się wycierpieli to wycierpieli, ale Hitler przynajmniej uwolnił Polskę od Żydów”. Nasza przygoda w tym procesie historycznej korekty rachunków krzywd została zakwalifikowana jako mimowolna i marginalna („margines przestępczy”), ale ciągle wypierana pamięć o niej nie przestała być problemem. Ta oczekiwana zamiana została przesłonięta inną, czyli powojennym przejęciem własności niemieckiej i zajęciem miejsca Niemców, co było uznane przez ogół społeczności polskiej za akt sprawiedliwości dziejowej, słuszną karę za wywołanie wojny.

Czytelnicy Ledera z obozu pretendującego do reprezentowania narodowej większości na ogół nie wdawali się w uczoną polemikę, po prostu zbagatelizowali ją jako „książkę bałamutną”, mętny wywód podejrzanego autoramentu polegający na wmówieniach ${ }^{24}$. Nie stała się ona przedmiotem rozmowy w prawicowych gazetach i na portalach.

Doświadczeniu temu „towarzyszy jednocześnie swoiste poczucie pasywności i przypomina sytuację podmiotu we śnie. Wszystko dzieje się, ale jakby samo, poza podmiotową władzą, która polega na poczuciu sprawstwa swoich czynów, które nazywa się wolą", A. Leder Prześniona rewolucja, Wydawnictwo Krytyki Politycznej, Warszawa 2014, s. 21-22.

Por. A. Horubała Nieświadome zbrodnie Polaków, "Do Rzeczy” 2014 nr 3, http://dorzeczy.pl/ kultura/id,3482/Nieswiadome-zbrodnie-Polakow.html (10.08.2016). Recenzent "Teologii Politycznej” książkę Ledera, "której prawicy brakuje” - jak napisał - uznał zarazem za "bełkotliwą” i „niewolną od ideologicznej tendencyjności”. Por. P. Rzewuski Na marginesie. Andrzej Leder, Prześniona rewolucja, "Teologia Polityczna” 2014 nr 6, s. 20. Ukazała się także bardziej wnikliwa polemika, ale dotyczyla ona nie kryminalnego, ale ekonomicznego aspektu przewłaszczenia opisanego przez Ledera. "Leder nie zauważył słonia w salonie, nie dostrzegł, że przyłączenie niemieckich ziem wschodnich, przymusowe, dokonane z użyciem przemocy, wysiedlenie 10 mln Niemców i uwłaszczenie na ich majątku było wielką narodowo-społeczną i geograficzno-przestrzenną rewolucją! I nie była to „prześniona rewolucja”. Por. T. Gabiś Polish middle class 


\section{4.}

Czy z sytuacji bez wyjścia istnieje zatem jakieś wyjście? Czy można wyjść z zaklętego koła kompulsywnych powtórzeń? Zaklętego, bo „przymusowe powtarzanie sytuacji nieprzyjemnych czy wręcz bolesnych, uznawane za niepodważalny fakt widoczny w doświadczeniu analitycznym ma swoje niewyczerpywalne źródła w życiu popędowym"25. Co więcej, jak powiadają lacaniści, powtarzaniu nie ma końca, choć wypada dodać, że zalecenie „Enjoy your symptom” brzmi tu cokolwiek niestosownie, a i zgoła niezgodnie z linią myślenia samego Freuda, który we wspomnianym tekście o przypominaniu pisat:

W szczególności ludzie niedojrzali i dziecinni w trakcie postępowania terapeutycznego ową konieczność traktowania swej choroby z powagą skłonni są przyjmować jako wymówkę dla delektowania się swymi symptomami. ${ }^{26}$

W swoim artykule Freud za warunek pomyślnej kuracji uznawał ni mniej ni więcej tylko „odwagę”, z jaką pacjent gotów jest przeciwstawić się swojej chorobie. Łatwiej wyjść z zaklętego koła powtórzeń jednostce decydującej się na bezwzględną wobec siebie, pracochłonną (nie mówiąc już: kosztowną) terapię, aniżeli zbiorowości napędzającej się lękowo swoim gniewem i fiksującej się na pozycjach ofiary ${ }^{27}$. W tym wypadku chodzi o leczenie przez dyskurs publiczny. Ale i tu warunkiem koniecznym jest fortunne terapeutycznie "przeniesienie": w przełożeniu na realia i warunki debaty oznacza to co najmniej wolę rozmowy i wspólne uznanie standardów do oceny użytych w niej argumentów. Publiczny dyskurs terapeutyczny wydaje się pracą na

erwache!, albo co prześnił Andrzej Leder, http://nowadebata.pl/2016/07/29/polish-middleclass-erwache-albo-co-przesnil-andrzej-leder/ (10.08.2016).

J. Laplanche, J--B. Pontialis Przymus powtarzania, w: Słownik psychoanalizy, s. 267.

S. Freud The Complete works, s. 153.

27 Psychologowie społeczni zwracają uwagę na trwanie niezaleczonej w Polsce wieloletniej psychicznej traumy wojennej, związanej z zagrożeniem życia i konfrontacją ze śmiercią (w niej upatrują kariery myślenia paranoicznego, społecznego braku zaufania, łatwości, z jaką ujawnia się mowa nienawiści). Por. P. Holas, M. Lis-Turlejska A w głowach wojna trwa, "Gazeta Wyborcza" 14-15 maja 2016, s. 38. Rozpoznania psychologów nie znalazły i nie znajdują w Polsce żadnego przełożenia na program terapii w skali społecznej (podobnie jak deklarowana przez historyków polskich znajomość zbrodni jedwabieńskiej przed publikacją książki Grossa nigdy nie przełożyła się na debatę przez nich zainicjowaną). 
miarę prac Heraklesa: przyjmowany dziś jako atak i kłamstwo, niemający ostatnio zupełnie wsparcia w instytucjach państwowych, wręcz przez nie dezawuowany jako szkalowanie narodowej wspólnoty, jawi się jako skazany na porażkę. Mamy dziś do czynienia z odrzuceniem dyskursu jako płaszczyzny uzgadniania perspektyw i argumentacji. Czy dlatego, że „nie godzi się rozmawiać z ludźmi, którzy nazywają się Polakami, ale nie są już Polakami"?28

Tymczasem dyskurs ma tu znaczenie zasadnicze, jako że jest on instrumentem wprowadzania zmian w społecznej pamięci. Uznaną przez badaczy prawdą jest to, że "publiczne obchodzenie się z pamięcią wpływa także na pamięć indywidualną, wyparcie może więc przyczynić się do zapomnienia", a nawet „narody mogą bezkarnie wypierać przeszłość, ich zbiorowa pamięć może być zmieniana bez «powrotu wypartego»" 29 - choć ta ostatnia teza budzi już wątpliwości. Niewątpliwie też pamięć publiczna, niezależnie od jej nieświadomych uwikłań, zależy od konstruowanych przez instytucje władzy reprezentacji przeszłości w taki sposób, by jednostki „postrzegały je jako własne". Rola instytucji, a zwłaszcza instytucji publicznego zaufania, jak choćby instytucje naukowe czy edukacyjne, jest tu zatem ogromnie ważna. Tym bardziej że partykularne reprezentacje przeszłości, które przenikają do sfery publicznej, , uosabiają społeczną, polityczną czy instytucjonalną intencjonalność, która ją wspiera bądź umożliwia"30.

W swoim dziele Pamięć, historia, zapomnienie Paul Ricoeur wiele uwagi poświęcił rozwiązaniu afektywnego konfliktu, którym jest zablokowana i zmanipulowana pamięć, oraz warunkom, na jakich może dokonać się przyswojenie wypieranych treści, tak aby ten proces służył zażegnaniu sporu zwaśnionych pamięci. W centrum jego rozważań znalazła się zdolność do zapomnienia stanowiącego finalny efekt całego procesu. Ricoeur, w miejsce pamięci zinstytucjonalizowanej i przez to często wystawianej na ryzyko nadużyć, proponuje instaurację pracy pamięci rozumianej tak, jak rozumiał ją właśnie Freud. Owej pracy pamięci, narażonej na pozostawanie niewolną od nacisków i manipulacji, towarzyszyć musi - jeśli ma osiągnąć swój cel - praca żałoby. Żałoba staje się tu utożsamiona z pamiętaniem. Żałoba, która jest akceptacją utraty drogiego nam obiektu (także w tym sensie można

28 J.M. Rymkiewicz w rozmowie z Joanną Lichocką, http://wpolityce.pl/kultura/280770-rymkiewicz-w-bardzo-waznej-rozmowie-z-lichocka-polacy-zrozumieli-ze-sa-wynaradawiani-zeto-wszystko-zmierza-do-likwidacji-polski-calosc (20.08.2016). 
rozumieć przywołane wcześniej słowa Freuda o akceptacji poczucia nieszczęścia). Dokonując własnej pracy żałoby, winniśmy zatem wypracować w sobie zdolność empatycznego traktowania naszych oponentów, tak aby zmierzać do pojednania, kulminującego w - jak je nazywa Ricoeur - „fortunnym zapomnieniu". Zatem zapomnienie - amnestia, nie jest amnezją, niepamięcią. Jest „wybaczaniem puszczającym w niepamięć", ale istotne są warunki, na których się ono dokonuje. Praca pamięci/żałoby winna znaleźć wymierne rezultaty. „Kwestia wybaczenia występuje tam, gdzie było oskarżenie, wyrok i kara” - powiada Ricoeur ${ }^{31}$. Ważny jest też „zbawienny kryzys tożsamości, który umożliwia świadome przejęcie przeszłości i jej traumatycznego balastu”, co dokonuje się właśnie za sprawą pracy pamięci, „zwieńczoną pracą żałoby i prowadzoną w duchu wybaczenia"32. Jest to więc zapomnienie niebędące zapomnieniem krzywdy, ale „wyrażaniem jej w sposób pokojowy, bez gniewu", wolą pojednania.

Niewątpliwie tego rodzaju proces byłby łatwiejszy, a i miałby większe szanse powodzenia, gdyby Polska otrzymała moralną rekompensatę za ogrom cierpień i strat, jakie poniosła w II wojnie światowej3. Niestety ignorancja i zapomnienie, z którymi w tym względzie mamy do czynienia w przypadku Zachodu - cytowane wcześniej zdanie Tony Judta, znaczącego przecież historyka i intelektualisty, jest tu symptomatyczne - nie zapowiadają tego. Ale też skądinąd nie jest wcale pewne, czy gdybyśmy stanęli wreszcie w blasku jupiterów, nie wzmocniłoby to tylko polskiego syndromu ofiary.

Nie trzeba być chyba aż Freudowskim pesymistą, żeby stwierdzić, że w warunkach, w jakich toczy się dzisiaj w Polsce dyskurs na temat pamięci, projekt filozofa, podobnie jak projekt Michaela Rothberga, okazuje się projektem niemożliwym. Jako czytelnicy filozofów jesteśmy przyzwyczajeni do porażek. Gorzej, że Polak pozostanie chorym człowiekiem Europy; jeszcze gorzej, że będzie z tego czerpał rozkosz.

P. Ricoeur Pamięć..., s. 596.

Tamże, s. 600.

Polska straciła 17,1 proc. swoich obywateli, liczba ofiar polskich Żydów jest mniej więcej równa liczbie pozostałych polskich ofiar. W tym względzie, a także jeśli chodzi o zniszczenia materialnego majątku, Polska zajmuje drugie, po ZSRR, miejsce wśród krajów zangażowanych w wojnę. Na Polskę oraz ZSRR przypadło aż 71\% zniszczeń na kontynencie. Por. M. Maciorowski lle milionów zginęło?, "Gazeta Wyborcza - Ale Historia” 4 maja 2016, s. 13, http://wyborcza.pl/alehistoria/1,121681,17844725,Ile_milionow_zginelo__Ofiary_II_wojny_swiatowej.html (26.08.2016). 


\section{Abstract}

\section{Marek Zaleski}

THE INSTITUTE OF LITERARY RESEARCH OF THE POLISH ACADEMY OF SCIENCES (WARSAW)

Our Obsessive Oblivion about the Holocaust

Zaleski describes the pathogenic mechanisms that come into play in Polish society: in the processes of forgetting the extermination of our fellow citizens, Polish Jews, during the last war, as well as in the reasons behind the construction of a false historical imagination/ imaginarium of collective memory. In the Polish affective economy, 'the Jews' are a symptom that allows a noisy'neurotic minority' to cast the collective in the role of victim,

to give permanence to phantasms and pathological structures in our collective identity. Zaleski also expresses his alarm at the fact thatcurrently, official public discourse once again sanctions those practices.

\section{Keywords}

anti-Semityzm, affect, phantasm, collective memory, identity 